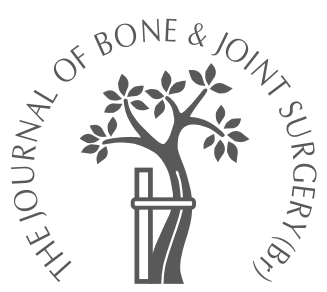

I. Henderson, B. Tuy, B. Oakes

From St Vincent's and Mercy Private Hospital, Melbourne, Australia

\title{
Reoperation after autologous chondrocyte implantation
}

\author{
INDICATIONS AND FINDINGS
}

We have reviewed 22 patients from a total of 135 treated by autologous chondrocyte implantation ( $\mathrm{ACl}$ ) who had undergone further surgery for pain in the knee and mechanical symptoms after a mean of $\mathbf{1 0 . 5}$ months. There were 31 grafted lesions. At operation the findings included lifting (24/31) and detachment (3/31) of periosteal patches for which arthroscopic shaving was performed. Chondroplasty was undertaken on two new lesions, another required an $\mathrm{ACl}$ and a further patient required trimming of a meniscus.

The mechanical symptoms resolved within two weeks. At the last review, two to 14 months from reoperation; $68 \%$ had improved, and $86 \%$ had normal or nearly normal IKDC scores. Of the 31 lesions, 30 (97\%) had normal or nearly normal visual repair scores.

Biopsy showed good integration with subchondral bone and the marginal interface in all specimens, most of which showed hyaline or hyaline-like cartilage $(\mathbf{7 0} \%)$. Troublesome mechanical symptoms required surgery in $13 \%$ of $\mathrm{ACl}$-treated patients and were attributed to periosteal extrusion. Simple arthroscopic debridement was curative.

In the last decade autologous chondrocyte implantation (ACI) has emerged as a viable and effective treatment for injury to articular cartilage with encouraging short-term results in regard to patient satisfaction and standard knee scores. ${ }^{1-12}$ Peterson et al ${ }^{13,14}$ and Brittberg et $\mathrm{al}^{15}$ have shown that these favourable results are maintained at medium-term follow-up and biopsies have shown the development of predominantly hyaline cartilage within the first 12 months. ${ }^{8-10,13,16}$ Nevertheless, adverse effects such as effusions, adhesions, synovitis and 'graft hypertrophy' may occur which may require reoperation. $3,4,11,12$

Our aim was to assess patients who have required further operation following ACI and to describe the surgical findings, procedures required, the clinical outcome and the results of biopsy.

\section{Patients and Methods}

Between November 2000 and November 2002, the senior author ( $\mathrm{IH}$ ) carried out autologous cartilage implantation for defects of the articular cartilage of the knee of grades 3 to 4 in 135 patients (181 lesions). This was done in two stages, as described by Peterson et al. ${ }^{14}$ Of these 135 patients, $22(16 \%)$ underwent reoperation (21 arthroscopic and one open) allowing us to assess $31(17 \%)$ grafted lesions. The mean age of the patients was 40 years (22 to 63) (Table I) and reoperations were performed at a mean of 10.5 months after the initial procedure (6 to 17). There were 15 men and seven women (14 left and eight right knees) and the mean size of the lesion was $3.3 \mathrm{~cm}^{2}$. All the lesions were on the femur except for two which were on the patella. We reviewed the patients' records to identify the symptoms, operative findings and procedures performed, and to assess the visual evidence for repair and the clinical outcome. The ICRS cartilage repair assessment form ${ }^{7}$ was used for visual grading at the second look. We took core biopsies from the surface through to the subchondral bone from the central portion and also at the margin with adjacent articular cartilage, using a Giebel needle (Karl Storz $\mathrm{GmbH}$, Tuttlingen, Germany) of $2 \mathrm{~mm}$ diameter. Patellar lesions were not biopsied because of difficulty in angling the needle at arthroscopy. Specimens were fixed with Ruthenium Red/osmium and embedded in Epon-Araldite. Sections $2 \mu \mathrm{m}$ in size were made before staining with Toluidine Blue.

Clinical outcome was measured by the International Knee Documentation Committee (IKDC) subjective assessment and objective examination forms. These were routinely completed before surgery and at 3, 6, 9, and 12 months afterwards. The clinical outcome after the reoperation was also assessed at the latest follow-up. 


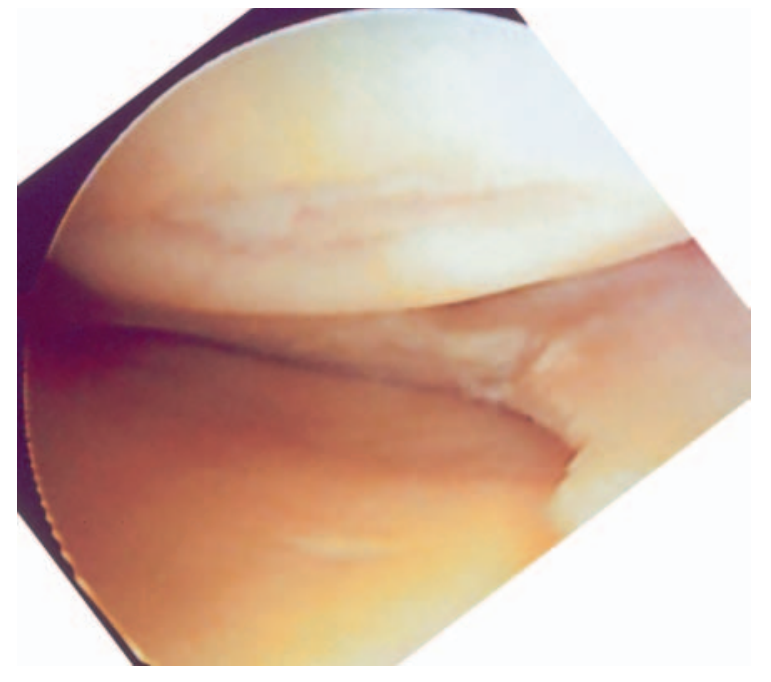

Fig. 1a

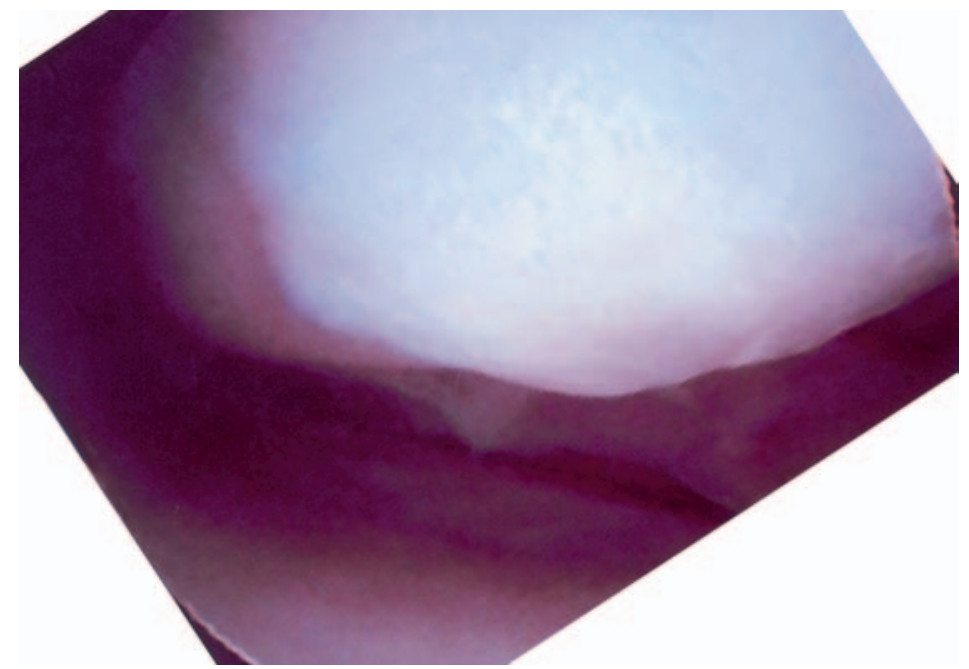

Fig. 1b

Arthroscopic appearance of $\mathrm{ACl}$ to the medial femoral condyle. a) before and b) nine-months after $\mathrm{ACl}$.

Table I. Details of the 22 patients

\begin{tabular}{cllrl}
\hline Case & $\begin{array}{l}\text { Age at time } \\
\text { of ACl (yrs) }\end{array}$ & Gender & $\begin{array}{l}\text { Months } \\
\text { from ACl }\end{array}$ & Indication for reoperation \\
\hline 1 & 37 & $\mathrm{M}$ & 10.0 & Catching \\
2 & 49 & $\mathrm{M}$ & 10.0 & Medial pain and catching \\
3 & 49 & $\mathrm{~F}$ & 9.0 & Medial pain; new trauma \\
4 & 63 & $\mathrm{M}$ & 7.0 & Medial pain and catching \\
5 & 45 & $\mathrm{M}$ & 14.0 & Clicking \\
6 & 22 & $\mathrm{~F}$ & 10.0 & Clicking \\
7 & 36 & $\mathrm{~F}$ & 9.0 & Catching \\
8 & 46 & $\mathrm{M}$ & 12.0 & Medial pain \\
9 & 52 & $\mathrm{~F}$ & 10.0 & Anterior pain and catching \\
10 & 27 & $\mathrm{M}$ & 12.0 & Asymptomatic; ROIF (HTO) \\
11 & 41 & $\mathrm{M}$ & 12.0 & Pain and catching \\
12 & 39 & $\mathrm{M}$ & 6.0 & Catching \\
13 & 42 & $\mathrm{~F}$ & 6.0 & Clicking and catching \\
14 & 46 & $\mathrm{M}$ & 16.0 & Catching \\
15 & 47 & $\mathrm{M}$ & 9.0 & Catching \\
16 & 34 & $\mathrm{M}$ & 9.0 & Clicking and catching \\
17 & 39 & $\mathrm{M}$ & 10.0 & Clicking and locking \\
18 & 33 & $\mathrm{~F}$ & 9.5 & Clicking and catching \\
19 & 37 & $\mathrm{M}$ & 13.0 & Clicking and medial pain \\
20 & 43 & $\mathrm{M}$ & 17.0 & Medial pain \\
21 & 36 & $\mathrm{M}$ & 13.0 & Clicking \\
22 & 25 & $\mathrm{~F}$ & 7.0 & Catching \\
Mean & 40 & & 10.5 & \\
\hline$*$ & & & & \\
\hline 1 & & & &
\end{tabular}

* removal of internal fixation for previous high tibial osteotomy

Thirteen patients had painless clicking or catching, five had painful clicking or catching, and three had knee pain only. One asymptomatic patient consented to second-look arthroscopy in conjunction with the removal of a staple from his previous high tibial osteotomy. In those with painless mechanical symptoms, there were no other remarkable findings on physical examination.

\section{Results}

At arthroscopy, we observed that periosteal patches were lifting off (24/31) which initially gave the impression of a protuberant graft (Fig. 1). In two cases, half of the patch was detached and half remained attached but protruding. Removal of the patch by careful arthroscopic shaving revealed good fill of the underlying neocartilage with minimal overgrowth. Most of the protuberance seemed to be due to the loosened patches since the underlying neocartilage had grown to fill the defect completely.

Of the five patients who complained of pain with mechanical symptoms, this was associated with concurrent knee pathology in three. One had a trochlear ACI and complained of medial pain at ten months. Arthroscopy revealed a new grade-III lesion of the medial femoral condyle. One with a graft of the medial femoral condyle complained of 'catching' associated with patellofemoral pain. MRI confirmed the presence of a grade-IV lesion of the trochlear cartilage for which cells were harvested at the second operation for later ACI. The third patient was a 63-year-old man who presented initially with predominantly patellofemoral symptoms and a discrete trochlear lesion but with evidence of degeneration of the medial compartment. He was particularly insistent on having ACI but, in retrospect, was not a suitable candidate. Seven months after ACI to the trochlea he developed medial pain and arthroscopy confirmed degeneration of the medial compartment of grade III to grade IV. Although he had good immediate relief from pain, he subsequently underwent knee replacement one year later. In two patients pain was attributed to the graft. One had had grafts to both the trochlea and medial femoral condyle, and the other had had a solitary trochlear graft. Arthroscopies revealed that the periosteal patches were 


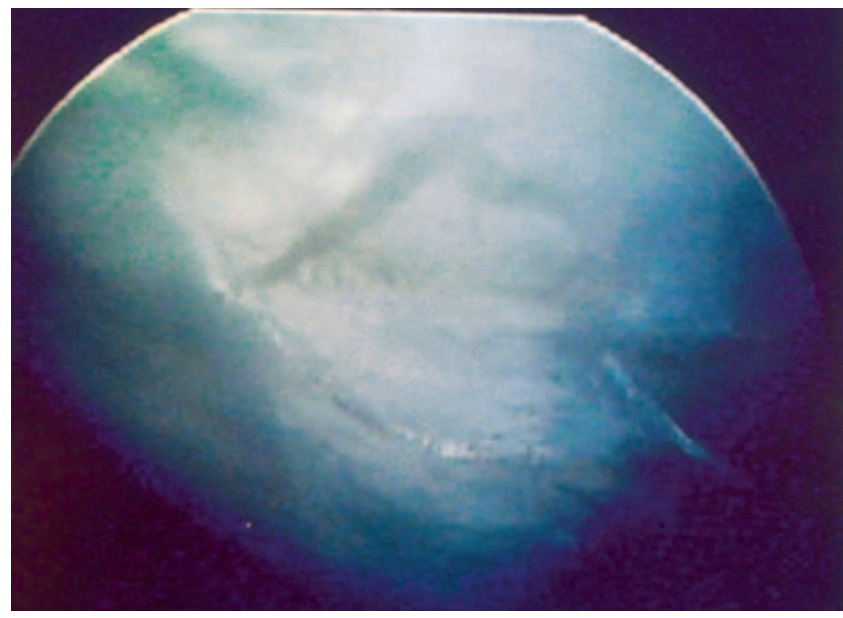

Fig. 2a

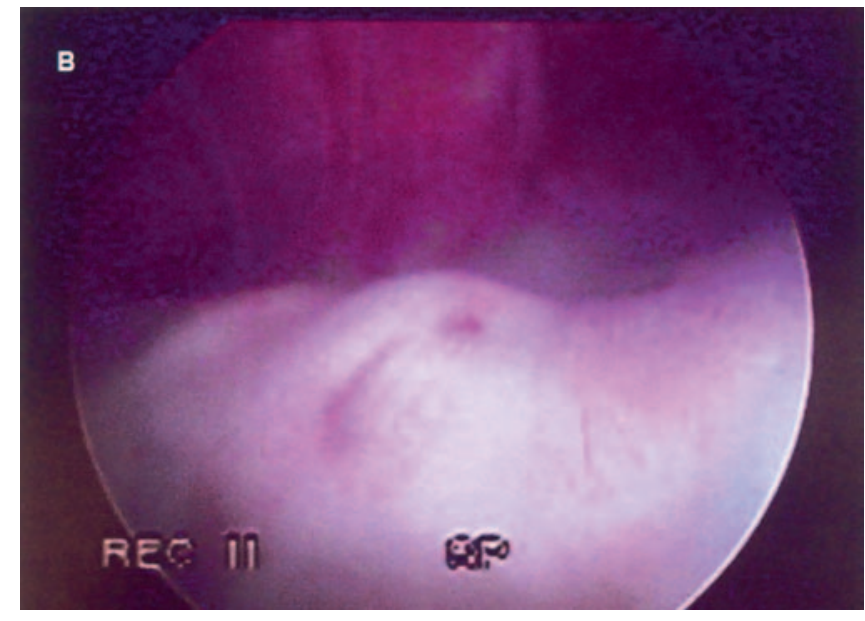

Fig. $2 b$

Arthroscopic appearance of the periosteal patch. a) Femoral condyle graft 12 months from ACl. The periosteum appears as a glistening, fibrous superficial layer. b) Trochlear graft ten months after ACl. The periosteal patch appears to be synovalised with some visible blood vessels.

loose and protruding from the surface. They were carefully shaved. Except for the patient with progressive arthritis, all five patients were free from pain at the last review.

Three patients complained of knee pain without mechanical symptoms. In two this was attributed to other disorders; one had suffered a further injury sustaining a tear of the medial meniscus nine months after ACI. At arthroscopy the tear in the anterior horn was resected together with a loose periosteal patch. Another patient developed a new chondral lesion of the medial femoral condyle which was treated by ACI in the only open second-look procedure. The site of the graft had good fill and no protuberance. The third patient complained of medial pain 17 months after ACI. MRI at ten months had shown subchondral bone oedema deep to the graft and arthroscopy revealed a loose patch. All three patients reported marked relief from pain within two weeks of reoperation and were free from pain at the last review.

The periosteal patches were identified by their glistening, fibrous appearance overlying the previous defects (Fig. 2a). In some cases, they showed surface blood vessels (Fig. 2b), which we did not appreciate on the histological sections. These appear to originate from the surrounding synovium as it has only been seen with lesions abutting synovial reflection with suture of the periosteal patch to the synovium. Although the exact role of the periosteal patch is yet undetermined, we feel that it functions primarily as a cap to seal in the grafted cells. Lastly, no synovitis or fibrous adhesions were noted.

Visual scoring at arthroscopy (Table II) gave a mean total score of 9.9 , and $97 \%$ of knees had normal or nearly normal ratings. The single abnormal score was in the patient with medial arthritic degeneration. Biopsies were performed as the last step, after shaving or removal of a patch. All 20 biopsy specimens showed good integration with subchondral bone. Hyaline articular cartilage with the characteristic zone pattern of articular cartilage was found in seven grafts $(35 \%)$. These showed a homogenous hyaline matrix with rounded chondrocytes contained in typical lacunae (Fig. 3). Hyaline-like cartilage was found in five $(25 \%)$, showing greater cell density in the deeper zones. In some specimens, periosteal elements were seen in the superficial layers (Fig. 4). Mixed fibro- and hyaline cartilage was observed in four grafts $(20 \%)$; these demonstrated a fibrocartilaginous superficial zone with a deeper hyaline-like component. The deep hyaline-like zones ended with a tidemark and a layer of calcified cartilage similar to normal articular cartilage. In biopsies at the margin of the graft, there was excellent integration with adjacent normal cartilage (Fig. 5). Definite fibrocartilage was seen in four grafts $(20 \%)$.

At the time of the second look, at a mean of 10.5 months from the ACI, 15 of the patients $(68 \%)$ reported subjective improvement (Table III); seven $(31.8 \%$ ) had normal IKDC knee examination scores while $11(50 \%)$ were classed as nearly normal because of a mild effusion. Abnormal knee scores were recorded in four, in three because of a moderate effusion and in one as a result of residual knee laxity from the original injury.

\section{Discussion}

Autologous chondrocyte implantation is a relatively new treatment for defects of articular cartilage. Adverse phenomena relating to it may not yet be fully appreciated and patients need to be properly advised and informed about what to expect when undergoing this treatment. Clinically significant events, some needing revision procedures, have been mentioned briefly in some studies including post-operative effusion, adhesions, arthrofibrosis, synovitis, hypertrophy of the periosteal patch and loosening of the graft 
Table II. ICRS visual assessment of repair and biopsy result

\begin{tabular}{|c|c|c|c|c|c|c|c|c|c|c|}
\hline $\begin{array}{l}\text { Patient } \\
\text { number }\end{array}$ & $\begin{array}{l}\text { Lesion } \\
\text { location }\end{array}$ & $\begin{array}{l}\text { Lesion } \\
\text { size } \\
\left(\mathrm{cm}^{2}\right)\end{array}$ & $\begin{array}{l}\text { Operative } \\
\text { findings* }\end{array}$ & Interventions † & $\begin{array}{l}\text { Degree of } \\
\text { defect } \\
\text { repair }\end{array}$ & $\begin{array}{l}\text { Integration } \\
\text { to border } \\
\text { zone }\end{array}$ & $\begin{array}{l}\text { Macroscopic } \\
\text { appearance }\end{array}$ & Total & $\begin{array}{l}\text { Overall repair } \\
\text { assessment }\end{array}$ & Biopsy result ‡ \\
\hline \multirow[t]{2}{*}{1} & MFC & 3 & LP & PR & 4 & 4 & 3 & 11 & $\begin{array}{l}\text { Nearly } \\
\text { normal }\end{array}$ & $\begin{array}{l}\text { Mixed } \\
\text { fibrohyaline }\end{array}$ \\
\hline & Trochlea & 1 & LP & PR & 3 & 3 & 3 & 9 & $\begin{array}{l}\text { Nearly } \\
\text { normal }\end{array}$ & $\begin{array}{l}\text { Mixed } \\
\text { fibrohyaline }\end{array}$ \\
\hline 2 & Trochlea & 5 & LP & $\begin{array}{l}\text { PR, Chondroplasty } \\
\text { of new MFC lesion }\end{array}$ & 4 & 3 & 4 & 11 & $\begin{array}{l}\text { Nearly } \\
\text { normal }\end{array}$ & NB \\
\hline 3 & MFC & 1.5 & LP & $\begin{array}{l}\text { PR, partial resection } \\
\text { of MM }\end{array}$ & 4 & 3 & 3 & 10 & $\begin{array}{l}\text { Nearly } \\
\text { normal }\end{array}$ & NB \\
\hline 4 & Trochlea & 2.5 & $\mathrm{DP}$ & PR & 2 & 1 & 1 & 4 & Abnormal & Fibrocartilage \\
\hline 5 & Trochlea & 4.5 & LP & PR & 4 & 2 & 3 & 9 & $\begin{array}{l}\text { Nearly } \\
\text { normal }\end{array}$ & NB \\
\hline 6 & Trochlea & 4 & LP & PR & 2 & 4 & 3 & 9 & $\begin{array}{l}\text { Nearly } \\
\text { normal }\end{array}$ & NB \\
\hline 7 & MFC & 2.25 & LP & PR & 4 & 2 & 2 & 8 & $\begin{array}{l}\text { Nearly } \\
\text { normal }\end{array}$ & NB \\
\hline \multirow[t]{2}{*}{8} & Trochlea & 1 & NG & $\mathrm{ACl}$ to $\mathrm{MFC}$ lesion & 4 & 3 & 3 & 10 & $\begin{array}{l}\text { Nearly } \\
\text { normal }\end{array}$ & Fibrocartilage \\
\hline & LFC & 3 & NG & & 4 & 3 & 3 & 10 & $\begin{array}{l}\text { Nearly } \\
\text { normal }\end{array}$ & NB \\
\hline 9 & MFC & 3.75 & LP & $\begin{array}{l}\text { PR, cell harvest for } \\
\text { trochlear } \mathrm{ACl}\end{array}$ & 4 & 3 & 2 & 9 & $\begin{array}{l}\text { Nearly } \\
\text { normal }\end{array}$ & $\begin{array}{l}\text { Hyaline } \\
\text { cartilage }\end{array}$ \\
\hline \multirow[t]{2}{*}{10} & LFC & 1.5 & NG & None & 4 & 4 & 3 & 11 & $\begin{array}{l}\text { Nearly } \\
\text { normal }\end{array}$ & $\begin{array}{l}\text { Hyaline } \\
\text { cartilage }\end{array}$ \\
\hline & MFC & 3.75 & NG & None & 4 & 3 & 3 & 10 & $\begin{array}{l}\text { Nearly } \\
\text { normal }\end{array}$ & $\begin{array}{l}\text { Hyaline } \\
\text { cartilage }\end{array}$ \\
\hline \multirow[t]{2}{*}{11} & Trochlea & 1.5 & LP & PR & 4 & 3 & 3 & 10 & $\begin{array}{l}\text { Nearly } \\
\text { normal }\end{array}$ & NB \\
\hline & MFC & 3 & LP & PR & 4 & 3 & 3 & 10 & $\begin{array}{l}\text { Nearly } \\
\text { normal }\end{array}$ & NB \\
\hline 12 & MFC & 6.25 & LP & PR & 4 & 3 & 3 & 10 & $\begin{array}{l}\text { Nearly } \\
\text { normal }\end{array}$ & NB \\
\hline \multirow[t]{2}{*}{13} & Patella & 1 & LP & PR & 3 & 3 & 3 & 9 & $\begin{array}{l}\text { Nearly } \\
\text { normal }\end{array}$ & NB \\
\hline & MFC & 1.5 & LP & PR & 4 & 4 & 4 & 12 & Normal & $\begin{array}{l}\text { Mixed } \\
\text { fibrohyaline }\end{array}$ \\
\hline 14 & MFC & 2.25 & DP & PR & 3 & 4 & 3 & 10 & $\begin{array}{l}\text { Nearly } \\
\text { normal }\end{array}$ & $\begin{array}{l}\text { Hyaline } \\
\text { cartilage }\end{array}$ \\
\hline 15 & MFC & 3 & $\mathrm{DP}$ & PR & 3 & 4 & 4 & 11 & $\begin{array}{l}\text { Nearly } \\
\text { normal }\end{array}$ & $\begin{array}{l}\text { Mixed } \\
\text { fibrohyaline }\end{array}$ \\
\hline \multirow[t]{2}{*}{16} & LFC & 8 & LP & PR & 4 & 3 & 3 & 10 & $\begin{array}{l}\text { Nearly } \\
\text { normal }\end{array}$ & $\begin{array}{l}\text { Hyaline } \\
\text { cartilage }\end{array}$ \\
\hline & Trochlea & 4 & LP & PR & 4 & 4 & 3 & 11 & $\begin{array}{l}\text { Nearly } \\
\text { normal }\end{array}$ & $\begin{array}{l}\text { Hyaline } \\
\text { cartilage }\end{array}$ \\
\hline \multirow[t]{2}{*}{17} & MFC & 8.75 & LP & PR & 4 & 3 & 3 & 10 & $\begin{array}{l}\text { Nearly } \\
\text { normal }\end{array}$ & $\begin{array}{l}\text { Hyaline-like } \\
\text { cartilage }\end{array}$ \\
\hline & Trochlea & 2.25 & LP & PR & 4 & 3 & 3 & 10 & $\begin{array}{l}\text { Nearly } \\
\text { normal }\end{array}$ & $\begin{array}{l}\text { Hyaline-like } \\
\text { cartilage }\end{array}$ \\
\hline 18 & MFC & 3 & LP & PR & 4 & 3 & 3 & 10 & $\begin{array}{l}\text { Nearly } \\
\text { normal }\end{array}$ & $\begin{array}{l}\text { Hyaline-like } \\
\text { cartilage }\end{array}$ \\
\hline 19 & Trochlea & 3 & LP & PR & 4 & 4 & 3 & 11 & $\begin{array}{l}\text { Nearly } \\
\text { normal }\end{array}$ & Fibrocartilage \\
\hline 20 & MFC & 4 & LP & PR & 4 & 4 & 3 & 11 & $\begin{array}{l}\text { Nearly } \\
\text { normal }\end{array}$ & $\begin{array}{l}\text { Hyaline-like } \\
\text { cartilage }\end{array}$ \\
\hline \multirow[t]{3}{*}{21} & LFC & 2.25 & LP & PR & 4 & 4 & 4 & 12 & Normal & $\begin{array}{l}\text { Hyaline } \\
\text { cartilage }\end{array}$ \\
\hline & MFC & 3 & LP & PR & 4 & 4 & 4 & 12 & Normal & $\begin{array}{l}\text { Hyaline } \\
\text { cartilage }\end{array}$ \\
\hline & Trochlea & 7.5 & LP & PR & 4 & 1 & 3 & 8 & $\begin{array}{l}\text { Nearly } \\
\text { normal }\end{array}$ & Fibrocartilage \\
\hline 22 & Patella & 2.25 & LP & PR & 4 & 3 & 3 & 10 & $\begin{array}{l}\text { Nearly } \\
\text { normal }\end{array}$ & NB \\
\hline Average & & 3.3 & & & 3.7 & 3.2 & 3.1 & 9.9 & & \\
\hline
\end{tabular}

* LP - loosened/lifted off periosteal patch; DP - detached periosteal patch; NG - normal looking graft

† PR - Patch removal; MFC - medial femoral condyle; medial meniscus

$\neq \mathrm{NB}-$ not biopsied 


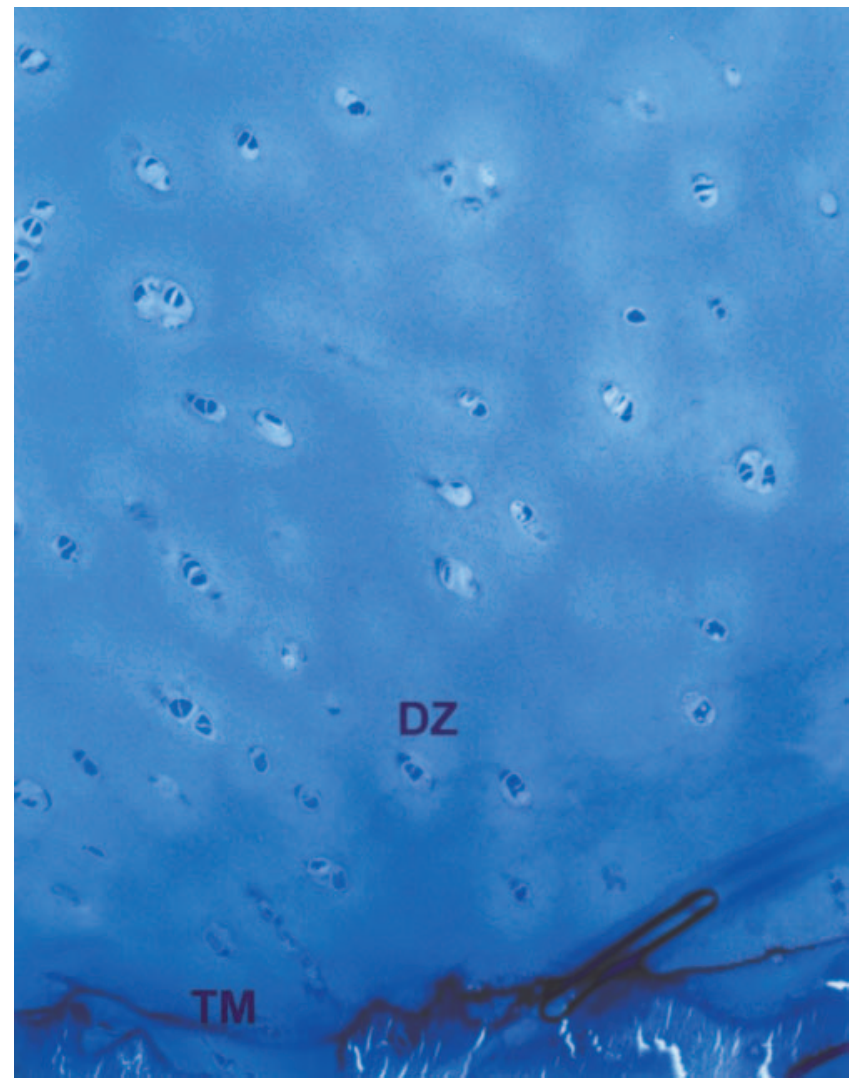

Fig. 3

Photomicrograph showing deep zone (DZ) of hyaline-like repair tissue. The tidemark (TM) is visible at the bottom (Toluidine Blue $\times 100$ ).

complex..$^{3,4,11,12}$ In our series of reoperated patients, 12 $(55 \%)$ still had an effusion at six months after ACI. Larger effusions were found with patellofemoral lesions. The reported incidence of adhesion ranges from $4.8 \%$ to $19.6 \% .^{6,8,11,14}$ Hart and Paddle-Ledinek ${ }^{8}$ noted adhesions in 11 patients, ten of whom had lesions affecting the patella. Mandelbaum ${ }^{11}$ reported synovitis in $2 \%$ of his patients. Hypertrophic growth has been described in between $2.4 \%$ and $20 \%$ of cases, ${ }^{6,11,17,18}$ while the overall need for further surgery as recorded in the literature ranges from $5.1 \%$ to $37 \% .^{2,4,11,14,17,18}$ It is not always clear from these studies what constitutes an indication for re-exploration; some have included purely diagnostic arthroscopies. In our series, troublesome mechanical symptoms necessitated arthroscopy in 18 patients, two of whom had graftrelated pain. Three patients had reoperation because of pain alone, but in two this was unconnected with the chondral graft. Thus, only 19 of 135 patients $(14 \%)$ had further surgery for problems related to the graft which were, mainly mechanical symptoms. ${ }^{18}$

Peterson et $\mathrm{al}^{14}$ reported what he termed 'periosteal hypertrophy' in 26 patients but only seven (13\%) produced clinical symptoms. They attributed this to frictional stimulation of the overlying periosteum, particularly six to 12

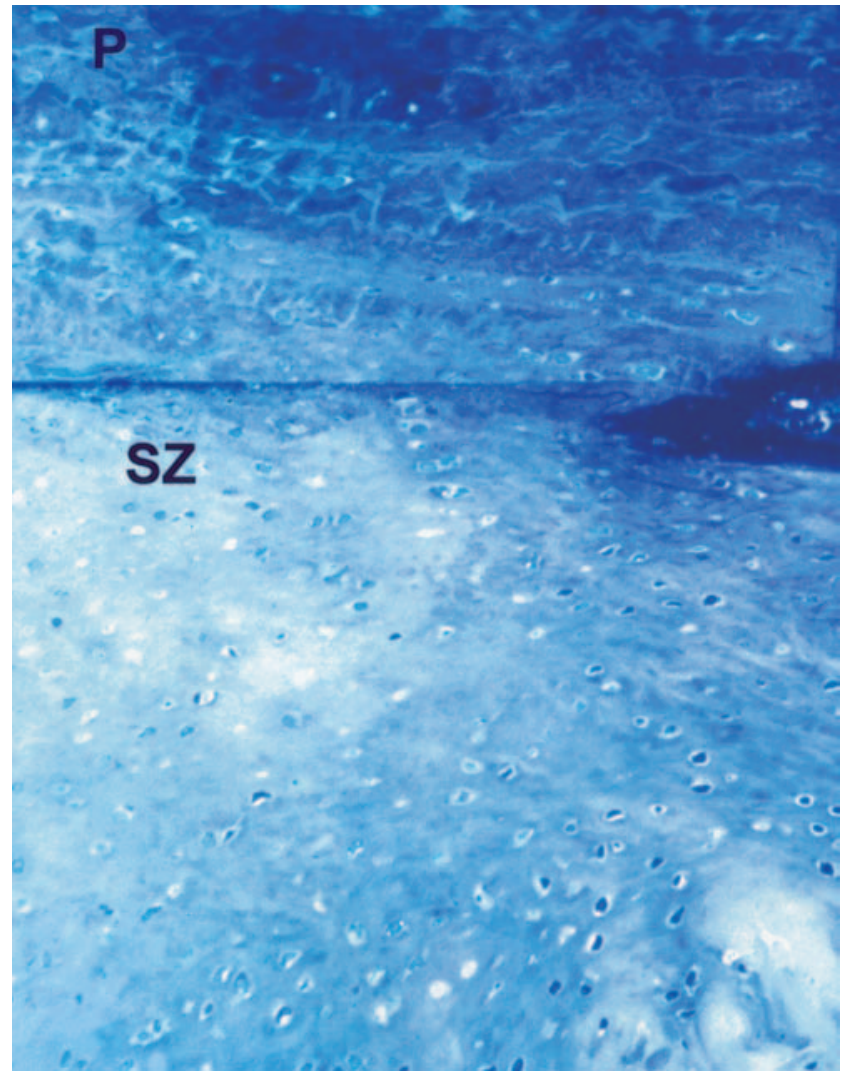

Fig. 4

Photomicrograph showing the superficial layer of the repair tissue. The periosteal patch is seen (P) overlying the superficial zone (SZ) of the repair tissue (Toluidine Blue $\times 100$ ).

months after implantation. Minas ${ }^{17,18}$ noted that $20 \%$ of patients treated by ACI needed an arthroscopy for periosteal hypertrophy which presented as painful 'catching' or

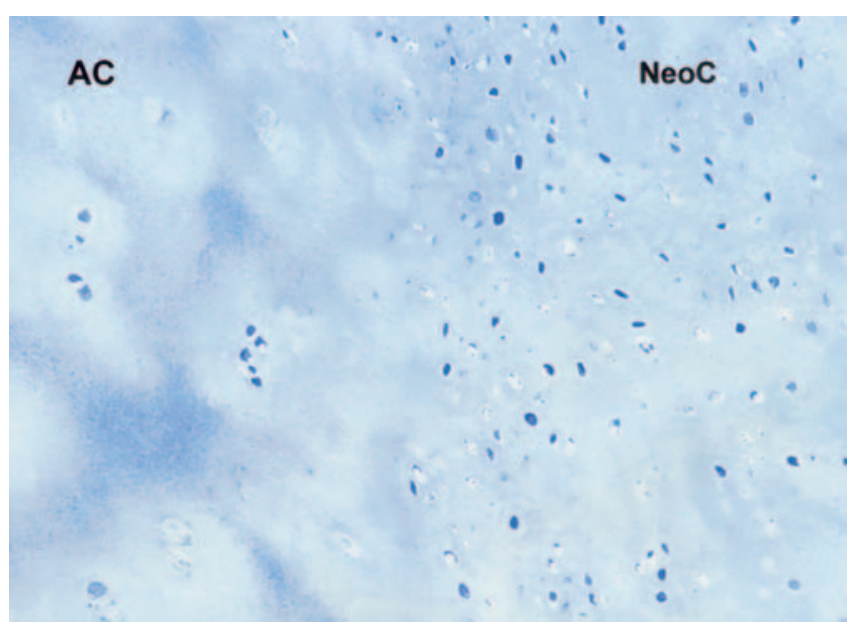

Fig. 5

Photomicrograph of a marginal biopsy showing the interface between the normal articular cartilage $(\mathrm{AC})$ and the neocartilage $(\mathrm{NeoC})$ at the site of repair (Toluidine Blue $\times 100$ ). 
Table III. Clinical outcome at time of reoperation

\begin{tabular}{|c|c|c|c|c|}
\hline Case & $\begin{array}{l}\text { Objective } \\
\text { IKDC at time } \\
\text { of } 2 \text { nd look }\end{array}$ & $\begin{array}{l}\text { Objective } \\
\text { IKDC at latest } \\
\text { follow-up }\end{array}$ & $\begin{array}{l}\text { Subjective } \\
\text { IKDC } \\
\text { evaluation, } \\
\text { pre-op }\end{array}$ & $\begin{array}{l}\text { Subjective IKDC } \\
\text { evaluation, at } \\
\text { time of } 2 \text { nd look }\end{array}$ \\
\hline 1 & $A$ & $A$ & 36.78 & 55.17 \\
\hline 2 & $\mathrm{C}$ & C & 57.47 & 71.26 \\
\hline 3 & B & A & 22.99 & 19.54 \\
\hline 4 & B & * & 27.59 & 43.68 \\
\hline 5 & C & C & 6.89 & 33.33 \\
\hline 6 & $B$ & A & 36.78 & 50.58 \\
\hline 7 & $A$ & A & 34.48 & 39.08 \\
\hline 8 & B & B & 55.17 & 74.71 \\
\hline 9 & B & A & 3.45 & 11.49 \\
\hline 10 & B & A & 52.87 & 58.62 \\
\hline 11 & $B$ & A & 42.2 & 19.5 \\
\hline 12 & A & A & 25.29 & 44.83 \\
\hline 13 & $C$ & A & 43.04 & 35.63 \\
\hline 14 & B & A & 78.31 & 48.26 \\
\hline 15 & A & A & 21.84 & 43.68 \\
\hline 16 & B & A & 33.3 & 46.0 \\
\hline 17 & C & A & 54 & 29.9 \\
\hline 18 & A & A & 57.5 & 48.1 \\
\hline 19 & B & A & 50.6 & 64.4 \\
\hline 20 & $A$ & A & 34.5 & 27.6 \\
\hline 21 & $A$ & A & 40.2 & 86.2 \\
\hline 22 & B & A & 39.1 & 46 \\
\hline Mean & & & 38.8 & 45.3 \\
\hline
\end{tabular}

* had TKR at 12 months

an effusion developing at four to nine months after surgery. In both studies, arthroscopic chondroplasty was followed by symptomatic relief.

As reported by Richardson et $\mathrm{al}^{19}$ "the role of the periosteum requires clarification as to whether it is simply a mechanical restraint for the grafted chondrocytes or whether it provides factors and/or cells which may influence the repair process". Some authors have been unable to show any enhancing effect of periosteum on cell proliferation and cell numbers in chondrocyte cultures. ${ }^{20}$ We believe that the prominence of the periosteal patch does not reflect a true hypertrophy of periosteum but rather the mechanical extrusion of the periosteal patch brought on by growth of the underlying neocartilage.

The mean score for the appearance of incorporation in our series is similar to that of other studies. ${ }^{1,8,9,14}$ Of the three parameters assessed by the ICRS scoring system, filling of the depth of the defect was the most consistent (mean score 3.7 out of 4), as has been reported by others. ${ }^{10,14,16,21,22}$ The results of the biopsy showed hyaline or hyaline-like cartilage in $60 \%$, mixed fibrohyaline cartilage in $20 \%$, and definite fibrocartilage in $20 \%$. All four fibrocartilage biopsies were from trochlear lesions and were graded $\mathrm{A}$ or $\mathrm{B}$, according to the categories of IKDC. One graft described as fibrocartilage on the specimen, was rated as abnormal on arthroscopic visualisation; the rest were graded nearly normal. This suggests that visual grading is of limited use since, by itself, it does not differentiate the type of repair tissue formed. If supplemented with quanti- tative probing or indentometry, arthroscopic visualisation may give information which approaches the usefulness of core biopsy.

In the first 12 months after ACI we have not seen adhesions, synovitis or arthrofibrosis. Effusion was common but bothersome mechanical symptoms were the principal adverse sequelae, bringing $13 \%$ of cases to repeat operation. We attribute these to periosteal extrusion rather than periosteal or graft hypertrophy. While we do not recommend routine arthroscopy at one year, arthroscopic debridement reliably resolved these mechanical symptoms. These were usually painless. When pain was present, it was usually associated with different pathology. Arthroscopic shaving and biopsy did not adversely affect the clinical outcome in the short term since the patients' knee scores continued to improve up to 14 months after reoperation.

No benefits in any form have been or will be received from a commercial party related directly or indirectly to the subject of this article.

\section{References}

1. Bentley G, Biant LC, Carrington RJW, et al. A prospective, randomized comparison of autologous chondrocyte implantation versus mosaic plasty for osteochondral defects in the knee. J Bone Joint Surg [Br] 2003;85-B:223-30.

2. Brown JE, Erggelet C, Fu FH, et al. A controlled study of autologous chondrocyte implantation versus debridement for full-thickness articular cartilage lesions of the femur: results at 3 years. ISAKOS Congress. Montreux, Switzerland 2001.

3. Brown JE, Erggelet C, Fu FH, et al. 5-year multicenter outcome of autologous chondrocyte implantation of the knee. ISAKOS Congress. Montreux, Switzerland 2001.

4. Erggelet C, Browne JE, Fu F, et al. Autologous chondrocyte transplantation for treatment of cartilage defects of the knee joint. Zentralb/ Chir 2000;125:516-22.

5. Erggelet C, Steinwachs MR, Reichelt A. The operative treatment of full thickness cartilage defects in the knee joint with autologous chondrocyte transplantation. Saudi Med J 2000;21:715-21.

6. Gillogly SD, Voight M, Blackburn T. Treatment of articular cartilage defects of the knee with autologous chondrocyte implantation. J Orthop Sports Phys Ther 1998;28: 241-51.

7. Georgoulis A, Moebius E, Beris A, Papageorgiou C, Soucacos PN. Cartilage repair using autogenous chondrocytes in 12 patients. 2nd Symposium International Cartilage Repair Society, 1998.

8. Hart JA, Paddle-Ledinek J. Arthroscopic evaluation of cartilage repair following autologous chondrocyte implantation (ACI). SAKOS Congress 2001.

9. Löhnert J. Indication, technique and results after ACT (Autologous chondrocyte transplantation). ISAKOS Congress 2001.

10. Mahroof S, Briggs TWR, David LA, Pringle J, Bayliss M. Autologous chondrocyte transplantation: histological evaluation one year following surgery. 4th Symposium International Cartilage Repair Society, 2002.

11. Mandelbaum B. Autologous chondrocyte implantation of the knee: 3 year outcomes for isolated lesions of the femur. AAOS Annual Meeting, 2001.

12. Micheli LJ, Browne JE, Erggelet C, et al. Autologous chondrocyte implantation of the knee: multicenter experience and minimum 3-year follow-up. Clin J Sport Med 11: 223-8

13. Peterson L, Brittberg M, Kiviranta I, Akerlund EL, Lindahl A. Autologous chondrocyte transplantation: biomechanics and long-term durability. Am J Sports Med 2002;30:2-12.

14. Peterson L, Minas T, Brittberg $\mathbf{M}$, et al. Two- to nine-year outcome after autologous chondrocyte transplantation of the knee. Clin Orthop 2000;374:212-34.

15. Brittberg M, Talheden T, Sjogren-Jansson B, Lindahl A, Peterson L. Autologous chondrocytes used for articular cartilage repair: an update. Clin Orthop 2001; 391(Suppl):337-48

16. Papageorgiou CD, Charitos CV, Tokis $\mathbf{A}$, et al. Six years experience of autologous chondrocytes implantation for treatment of knee cartilage defects. 4th Symposium International Cartilage Repair Society, 2002.

17. Minas T. Autologous chondrocyte implantation for focal chondral defects of the knee. Clin Orthop 2001;391(Suppl):349-61.

18. Minas $\mathbf{T}$. The role of cartilage repair techniques, including chondrocyte transplantation, in focal chondral knee damage. Instr Course Lect 1999; 48:629-43. 
19. Richardson JB, Caterson B, Evans EH, Ashton BA, Roberts S. Repair of human articular cartilage after implantation of autologous chondrocytes. J Bone Joint Surg [Br] 1999;81-B:1064-8.

20. Oakes BW, Chaipinyo K, Van Damme MP. The role of periosteum and collagen scaffolds in cartilage transplantation. Combined Orthopaedic Meeting 2002.
21. Peterson L. Osteochondritis of the knee treated with autologous chondrocyte transplantation [abstract]. ISAKOS Congress, 2001.

22. Vasara A, Vuorenmaa M, Jurvelin JS, et al. Arthroscopic indentation analysis and clinical follow-up 1 year after autologous chondrocyte transplantation. 4th Symposium International Cartilage Repair Society, 2002. 